\title{
EFEKTIVITAS MODEL STM (SAINS TEKNOLOGI MASYARAKAT) TERHADAP PEMAHAMAN SISWA PADA KONSEP ENERGI DAN PERUBAHANNYA DI SEKOLAH DASAR
}

\author{
(Eksperimen Kuasi pada Siswa Kelas IV SDN Cipaku 03 dan SDN Nangela \\ Kecamatan Paseh Kabupaten Bandung) \\ Fery Muhamad Firdaus, M.Pd \\ STKIP Subang \\ fey.firdaus@gmail.com
}

\begin{abstract}
The research objective was to determine the influence of STM (Science Society Technology) of the elementary school students' understanding. The study was conducted in the second semester of academic year 2012-2013 at the State Primary School Cipaku 03 as the experimental group, and at the State Primary School Nangela as a control group. The research sample of 20 students from each group. During the research process, the experimental group was given STM (Science Society Technology), while the control group was given conventional learning. The approach used in this study is a quantitative approach with quasi experimental design method nonequivalent groups pretest-posttests. Data analysis was performed using t-test. 0.05 significance level. The results showed a significant difference between the scores of students' understanding of the experimental group and the control group. It also found that the STM (Science Society Technology) is more effective in improving students' understanding compared to conventional learning, so that the STM (Science Society Technology) can be an alternative to learning that can be applied in an effort to improve understanding of elementary school students.
\end{abstract}

Keywords: STM (Science Society Technology), Comprehension, Mathematics Education, Class IV, Elementary School.

\begin{abstract}
ABSTRAK
Tujuan penelitian adalah untuk mengetahui pengaruh STM (Sains Teknologi Masyarakat) terhadap pemahaman siswa sekolah dasar. Penelitian dilakukan pada semester 2 tahun akademik 2012-2013 di Sekolah Dasar Negeri Cipaku 03 sebagai kelompok eksperimen, dan di Sekolah Dasar Negeri Nangela sebagai kelompok kontrol. Sampel penelitian yaitu 20 siswa dari masing-masing kelompok. Selama proses penelitian, kelompok eksperimen diberikan STM (Sains Teknologi Masyarakat), sedangkan kelompok kontrol diberikan pembelajaran konvensional. Pendekatan penelitian yang digunakan yaitu pendekatan kuantitatif dengan metode eksperimen kuasi desain nonequivalent groups pretest-posttests. Analisis data dilakukan dengan uji-t. Tingkat signifikansi 0,05. Hasil penelitian menunjukkan perbedaan yang signifikan antara skor pemahaman siswa dari kelompok eksperimen dan kelompok kontrol. Hal ini juga menemukan bahwa STM
\end{abstract}




\section{Didaktik : J urnal Pendidikan Guru Sekolah Dasar, ISSN : 2477-5673 \\ Sekolah Tinggi Keguruan dan Ilmu Pendidikan Subang \\ Volume I Nomor 1, Desember 2015}

(Sains Teknologi Masyarakat) lebih efektif dalam meningkatkan pemahaman siswa dibandingkan dengan pembelajaran konvensional, sehingga STM (Sains Teknologi Masyarakat) dapat menjadi alternatif pembelajaran yang dapat diterapkan dalam upaya meningkatkan pemahaman siswa sekolah dasar.

Kata Kunci: STM (Sains Teknologi Masyarakat), Pemahaman, Pendidikan Matematika, Kelas IV, Sekolah Dasar.

\section{PENDAHULUAN}

IImu Pengetahuan, Teknologi, Informasi, dan Komunikasi (IPTEK) yang berkembang pesat menuntut Sumber Daya Manusia (SDM) yang berkualitas. Upaya untuk menciptakan SDM yang berkualitas bukanlah perkara mudah, dibutuhkan upaya-upaya yang nyata dari berbagai pihak termasuk pemerintah. Ada beberapa upaya yang ditempuh pemerintah, salah satu usaha itu ialah dengan meningkatkan kualitas pendidikan, Pemerintah menyadari bahwa dengan pendidikan yang berkualitas dapat meningkatkan kualitas SDM. Pendidikan merupakan salah satu upaya untuk mencerdaskan kehidupan bangsa, sebab pendidikan merupakan jalur yang sangat strategis untuk meningkatkan kualitas sumber daya manusia, dalam rangka meningkatkan kualitas hidup manusia, pada intinya pendidikan adalah untuk memanusiakan manusia, mendewasakan, merubah perilaku, serta meningkatkan kualitas menjadi lebih baik.

Pendidikan dapat diperoleh melalui pendidikan formal, informal dan nonformal. Dalam pendidikan formal salah satu jenjang pendidikannya yaitu pendidikan di sekolah dasar (SD), dimana pendidikan di SD ini merupakan awal pembentukan kepribadian dan pengetahuan bagi anak. Oleh karena itu, pendidikan di SD ini sangatlah penting manakala dilaksanakan secara efektif dan efisien sesuai denagn tujuan pendidikan di SD.

$$
\text { Pembelajaran merupakan }
$$

kegiatan pembahasan mengenai materi pembelajaran yang dijadikan bahan untuk siswa melakukan proses belajar, dimana pembelajaran ini juga merupakan faktor penting dalam meningkatkan mutu pendidikan, karena melalui pembelajaranlah tujuan pendidikan dapat tercapai, oleh karena itu sangatlah penting manakala guru memperhatikan kualitas pembelajaran di kelas, sehingga tujuan pendidikan dapat tercapai sesuai dengan yang diharapkan.

Dalam rangka meningkatkan kualitas pembelajaran, guru dapat melakukan variasi-variasi dalam pebelajaran supaya meningkatkan pemahaman dan hasil belajar siswa, salah satu variasi pembelajaran tersebut dapat dilakukan dengan mengimplementasikan model-model pembelajaran yang sesuai dengan tahap perkembangan dan karakteristik siswa, sehingga guru harus memiliki pengetahuan yang luas mengenai model-model pembelajaran yang sesuai dengan tahap perkembangan dan karakteristik siswa, serta dapat mengimplementasikannya pada kegiatan belajar mengajar.

Salah satu model pembelajaran yang dapat dilaksanakan oleh guru untuk meningkatkan pemahaman siswa yaitu model STM (Sains Teknologi Masyarakat). Model SainsTeknologi-Masyarakat (STM) yaitu 
suatu desain pembelajaran yang berusaha untuk menjembatani materi di dalam kelas dengan situasi dunia nyata di luar kelas yang menyangkut perkembangan teknologi dan situasi sosial kemasyarakatan. Model pembelajaran ini dilaksanakan untuk mempersiapkan siswa dalam menghadapi masa depannya, dimana model ini menuntut agar siswa diikutsertakan dalam penentuan tujuan, perencanaan, pelaksanaan, cara mendapatkan informasi, dan evaluasi pembelajaran.

\section{TINJAUAN TEORITIS}

\section{SAINS TEKNOLOGI MASYARAKAT}

Istilah Sains Teknologi

Masyarakat diterjemahkan dari bahasa Inggris Science Technology Society, yang pada awalnya dikemukakan oleh Jhon Ziman dalam bukunya Teaching and Learning About Science and Society. Pembelajaran science technology society berarti menggunakan teknologi sebagai penghubung antara sains dan masyarakat (Poedjiadi, 2005: 99).

Tujuan dari pembelajaran dengan menggunakan model STM di SD yaitu untuk mempersiapkan siswa SD menjadi anggota masyarakat yang mampu menerapkan pengetahuan ilmiah dan mengamalkan nilai-nilai sains untuk mewujudkan tatanan kehidupan masyarakat yang dapat emmecahkan masalah di lingkungan sekitarnya. Model STM ini juga membantu siswa dan masyarakat untuk memiliki literasi sains dan teknologi. Hal ini perlu dikembangkan sejak dini melalui bangku sekolah, karena model STM secara tidak langsung mendidik siswa SD menjadi warga masyarakat yang sadar sains dan teknologi. Dengan demikian diharapkan para siswa SD mempunyai gagasan untuk peduli pada lingkungan sekitar dan peduli pada isu-isu yang berkembang di lingkungannya serta mampu mengatasi isu-isu tersebut dengan menerapkan pengetahuannya (Yuliariatiningsih \& Irianto, 2008: 4344).

Raja (2009) mengungkapkan bahwa keputusan yang dibuat oleh masyarakat biasanya memerlukan penggunaan teknologi untuk melaksanakannya. Bahkan, masyarakat dan ilmu pengetahuan menggunakan teknologi sebagai sarana untuk menyimpan informasi. Peranan penting yang dimiliki oleh teknologi dapat berfungsi sebagai sarana tindakan dan penyidikan dalam pendekatan STM. Data juga menyiratkan sifat ilmu pengetahuan sebagai sebuah bidang di semua masyarakat.

Sains merupakan suatu tubuh pengetahuan (body of knowledge) dan proses penemuan pengetahuan. Teknologi merupakan suatu perangkat keras ataupun perangkat lunak yang digunakan untuk memecahkan masalah bagi pemenuhan kebutuhan manusia. Sedangkan masyarakat adalah sekelompok manusia yang memiliki wilayah, kebutuhan, dan normanorma sosial tertentu. Sains, teknologi dan masyarakat satu sama lain saling berinteraksi (Widyatiningtyas, 2009). Widyatiningtyas (2009) juga mengungkapkan bahwa pendekatan STM dapat menghubungkan kehidupan dunia nyata anak sebagai anggota masyarakat dengan kelas sebagai ruang belajar sains. Proses pendekatan ini dapat memberikan pengalaman belajar bagi anak dalam mengidentifikasi potensi masalah, mengumpulkan data yang berkaitan dengan masalah, mempertimbangkan 
solusi alternatif, dan mempertimbangkan konsekuensi berdasarkan keputusan tertentu.

Karakteristik

model pembelajaran STM yaitu pembelajaran yang mengaitkan antara sains, teknologi dan masyarakat, dimana proses belajarmengajarnya dilandari prinsip bahwa anak membentuk atau membangun pengetahuannya melalui interaksinya dengan lingkungan. Serta dalam pengajarannya terkandung lima ranah, yang terdiri atas ranah pengetahuan, ranah sikap, ranah proses sains, ranah pemahaman, dan ranah hubungan dan aplikasi.

Model pembelajaran STM ini dapat diterapkan pada proses pembelajaran di SD dengan tujuan untuk melatih kemampuan berpikir siswa mengenai hubungan sains, teknologi dan masyarakat dalam kehidupan sehari-hari, sehingga diharapkan hasil belajar yang diperoleh siswa dapat dicapai secara maksimal. Akan tetapi model pembelajaran STM ini pun memiliki keunggulan dan kelemahannya tersendiri, keunggulan dan kelemahannya tersebut diantaranya:

1. Keunggulan model pembelajaran STM di SD
a. Pembelajaran STM dapat meningkatkan kemampuan kritis, logis, maupun kreatif. berpikir siswa, baik berpikir
b. Melatih siswa memecahkan masalah yang ada di lingkungan sekitar.
c. Melatih siswa untuk mampu mengambil keputusan dalam mengatasi masalah yang dan masyarakat. menyangkut sains, teknologi

2. Kelemahan model pembelajaan STM di SD

a. Memerlukan waktu yang relatif lama karena guru harus merancang pembelajaran yang mengaitkan hubungan antara sains, teknologi dan masyarakat.

b. Menuntut guru untuk mempunya wawasan yang luas untuk mencari isu atau masalah yang terkait dengan topik pembahasan, serta guru harus tanggap terhadap masalah lingkungan.

Dalam melaksanakan proses pembelajaran dengan menggunakan model STM di SD ini, ada beberapa tahapan pembelajaran yang harus dilaksanakan oleh guru, adapun menurut Yuliariatiningsih \& Irianto (2008: 45) tahapan pembelajaran STM tersebut diantaranya:

1. Tahap invitasi

Pada tahap ini siswa didorong untuk mengemukakan pengetahuan awalnya tentang konsep yang akan dibahas yang berhubungan dengan masalahmasalah yang berhubungan denagn isu-isu di daerah sekitar lingkungan siswa, nasional, atau global.

2. Tahap ekplorasi

Pada tahap ini siswa dilibatkan secara aktif untuk membentuk konsep melalui konstruksi pengetahuannya sendiri melalui observasi, eksperimen, diskusi, atau surfing di internet. Pada tahap ini siswa diajak untuk memenuhi rasa keingintahuannya tentang masalah atau isu yang sedang hangat di masyarakat. Pada tahap ini pula siswa didorong untuk menggunakan keterampilan proses sains dalam mencari solusi tentang permasalahan.

3. Tahap penjelasan dan solusi

Pada tahap ini, konsep yang telah dibangun oleh siswa 
digunakan untuk menyelesaikan masalah atau menganalisis masalah yang telah dilontarkan pada awal pembelajaran. siswa dapat melaksanakan tindakantindakan konkrit yang didasari atas kepeduliannya terhadap lingkungan dan masyarakat sekitarnya.

4. Tahap pengambilan tindakan

Pada tahap ini siswa menggunakan pengetahuan dan keterampilannya untuk mengambil keputusan berupa kampanye atau ajakan untuk membuat laporan lisan maupun tulisan.

\section{PEMAHAMAN SISWA}

Pemahaman merupakan suatu kemampuan yang berada pada tingkatan kedua yang harus dimiliki siswa dan dijadikan tolak ukur evaluasi pembelajaran berdasarkan taxonomy bloom. Dimana pemahaman juga didefinisikan sebagai kemampuan untuk menyerap pengertian dari materi atau bahan yang dipelajari siswa di sekolah. Munaf (2001) mengemukakan bahwa: "Pemahaman merupakan salah satu jenjang kemampuan dalam proses berfikir dimana siswa dituntut untuk memahami yang berarti mengetahui sesuatu hal dan melihatnya dari berbagai segi".

Pada tingkatan ini, selain hafal mengenai konsep yang dipelajari, siswa juga harus memahami makna yang terkandung pada konsep tersebut, misalnya dapat menjelaskan suatu gejala, dapat menginterpretasikan grafik, bagan, diagram serta dapat menjelaskan konsep atau prinsip dengan kata-kata sendiri. Konsep adalah suatu gagasan yang menyeluruh mengenai hukum (prinsip, azas) atau teori yang mencakup berbagai hal yang terkandung dalam konsep tersebut, Darliana (Yunansah, 2010 : 21). Suatu konsep dibangun oleh unsurunsur konsep secara logis dan sistematis. Suatu konsep ditinjau dari segi aspek epistemologis memiliki empat unsur konsep penting, yaitu komposisi, fenomena, hukum, dan aturan.

Menurut Novak dan Gowin (Yunansah, 2010 : 21-22) pemahaman konsep juga dapat dievaluasi melalui peta konsep, guru dapat mengetahui tentang konsepkonsep yang telah dimiliki siswanya untuk mengaitkan informasi yang telah ada dalam struktur kognitif siswa. Aspek pemahaman merupakan aspek yang mengacu pada kemampuan untuk mengerti dan memahami suatu konsep dan memaknai arti suatu materi. Aspek pemahaman ini menyangkut kemampuan seseorang dalam menangkap makna suatu konsep dengan kata-kata sendiri. Pemahaman dapat dibedakan menjadi tiga kategori yaitu.

1. Menerjemahkan (translation)

$$
\text { Kegiatan pertama dalam }
$$

tingkatan pemahaman adalah kemampuan menerjemahkan. Kemampuan ini berkaitan dengan kemampuan siswa dalam menerjemahkan konsepsi abstrak menjadi suatu model simbolik sehingga mempermudah siswa dalam mempelajarinya.

2. Menafsirkan (interpretation)

Kemampuan ini lebih luas daripada menerjemahkan. Menafsirkan merupakan kemampuan untuk mengenal dan memahami ide utama suatu komunikasi.

3. Mengekstrapolasi (extrapolation)

Kemampuan pemahaman jenis ekstrapolasi ini berbeda dengan kedua jenis pemahaman lainnya dan memiliki tingkatan yang lebih tinggi. 


\begin{abstract}
Kemampuan pemahaman jenis ekstrapolasi ini menuntut kemampuan intelektual yang lebih tinggi, seperti membuat telaahan tentang kemungkinan apa yang akan berlaku.
\end{abstract}

\section{KONSEP ENERGI DAN KEGUNAANNYA \\ Setiap benda yang melakukan kegiatan atau usaha memerlukan energi. Energi adalah kemampuan untuk melakukan usaha.}

1. Energi Panas

a. Sumber Energi Panas
Semua yang dapat menimbulkan panas disebut sumber energi panas. Energi panas bermanfaat bagi kehidupan manusia. Misalnya mengeringkan pakaian, menyetrika pakaian dan mengeringkan ikan asin. Sumber utama panas di bumi adalah Matahari dan sumber lainnya adalah api dan gesekan antara dua benda. Api merupakan sumber energi panas yang dilepas ketika terjadi pembakaran. Energi panas juga bisa timbul karena adanya gesekkan antar dua benda. Makin kasar permukaan benda yang digesekan, makin cepat pula panas timbul.

\section{b. Perpindahan Panas}

Panas dapat berpindah dari sumbernya ketempat lain, akibatnya benda yang semula dingin dapat menjadi panas. Energi panas dapat berpindah melalui tiga cara yaitu:

1) Konduksi adalah peristiwa perambatan panas yang memerlukan suatu zat atau medium tanpa disertai adanya perpindahan bagian-bagian zat/medium tersebut. Contohnya, sendok terasa panas saat digunakan untuk mengaduk kopi panas.

2) Konveksi adalah perpindahan panas dengan disertai aliran zat perantaranya. Contohnya, peristiwa memasak air.

3) Radiasi adalah perpindahan panas tanpa zat perantara/medium.

Contohnya, sinar matahari yang sampai ke bumi dan panasnya kita dapat rasakan.

2. Energi Bunyi

a. Sumber Bunyi

Benda atau alat yang dapat menimbulkan bunyi disebut sumber bunyi. Misalnya, gong yang dipukul dan gitar yang dipetik. Telinga manusia yang normal hanya dapat menangkap bunyi yang memiliki frekuensi antara $20 \mathrm{~Hz}$ antara $20.000 \mathrm{~Hz}$. Bunyi yang frekuensinya antara 20-20.000 Hz disebut audisonik. Bunyi yang frekuensinya kurang dari $20 \mathrm{~Hz}$ disebut Infrasonik sedangkan frekuensinya di atas 20.000 Hz disebut ultrasonik.

b. Perambatan Bunyi

Gelombang bunyi termasuk gelombang mekanik yaitu gelombang yang memerlukan medium dalam perambatannya. Medium yang diperlukan bunyi untuk merambat dapat berupa gas, cair, dan padat. Contoh ketika bapak/ibu guru sedang berbicara di depan kelas, kamu dapat mendengar apa yang di bicarakan. Hal ini menunjukan bunyi dapat merambat melaui gas (udara).

3. Energi Alternatif

Contoh sumber energi alternatif adalah energi angin, 
energi air, dan energi panas panas bumi.

\section{a. Energi Angin}

Angin adalah sumber energi alternatif yang murah dan tidak mengakibatkan polusi. Energi angin juga dapat dipakai pada kincir angin yang dapat menggerakan turbin pada suatu pembangkit listrik.

\section{b. Energi Air}

Air mengalir dari tempat tinggi ke tempat yang lebih rendah. Aliran air yang deras merupakan sumber energi listrik. Energi ini dapat digunakan untuk menghasilkan energi listrik. Contohnya bendungan atau waduk yang menghasilkan arus yang deras sehingga bisa menggerakan turbin dan memutarkan generator listrik.

c. Energi Panas Bumi

Energi panas bumi adalah energi yang dihasilkan oleh magma didalam perut bumi. Energi panas di bumi disebut juga energi geotermal. Energi tersebut banyaknya di daerah pegunungan karena batuan panas yang terbentuk dapat memanaskan air sehingga dihasilkan sumber uap panas atau geiser. Sumber uap kemudian dibor. Uap panas yang keluar dari lubang pengeboran, setelah disaring dapat digunakan untuk menggerakan turbin yang akan memutarkan generator yang menghasilkan energi listrik. Contohnya pembangkit listrik yang ada di kawah kamojang di jawa tengah.

4. Perubahan Energi
a. Perubahan Energi gerak akibat pengaruh udara contonya parasut dan pesawat terbang.
b. Perubahan energi gerak menjadi energi bunyi

\author{
contohnya terompet dan \\ gendang (Wahyono: 2008).
}

\section{METODE PENELITIAN \\ Pendekatan Penelitian}

Pendekatan penelitian yang digunakan yaitu pendekatan kuantitatif, hal tersebut dikarenakan penelitian ini mengontrol bagaimana kelompok subjek penelitian diperlakukan dan kemudian mengukur bagaimana tindakan mempengaruhi setiap kelompok, sehingga diperlukan penelitian kuantitatif.

\section{Metode dan Desain Penelitian}

Metode yang digunakan dalam penelitian ini adalah eksperimen kuasi, hal ini dikarenakan penelitian dilaksanakan dengan maksud untuk mempelajari sesuatu dengan mengubah suatu kondisi dan mengamati pengaruhnya terhadap hal lain. Penelitian eksperimen kuasi yang akan dilaksanakan yaitu dengan bentuk nonequivalent groups pretestposttets design yang mengacu kepada pendapat Fraenkel dan Wallen (2007:278).

\section{Populasi dan Sampel}

Yang menjadi populasi dari penelitian ini adalah seluruh siswa kelas IV SDN Cipaku 03 dan SDN Nangela Kecamatan Paseh Kabupaten Bandung semester II tahun ajaran 2012-2013. Setiap masing-masing kelas diambil jumlah siswa yang sama sebagai sampel, yaitu sebanyak 20 siswa. Penempatan sampel pada kelompok eksperimen dan kelompok kontrol tidak dilakukan secara random atau acak, tetapi dilaksanakan secara non random.

\section{Instrumen}

Instrumen penelitian yang digunakan yaitu pedoman observasi 
dan lembar tes evaluasi pemahaman siswa pada konsep volume kubus dan balok. Pembuatan pedoman observasi pelaksanaan STM (Sains Teknologi Masyarakat) pada kelompok eksperimen, dan pembuatan pedoman observasi pelaksanaan pembelajaran konvensional pada penelitian di kelompok kontrol. Kegiatan evaluasi tes pemahaman siswa dilakukan dalam rangka mengetahui dan mengidentifikasi pemahaman siswa mengenai bahan ajar yang sedang dibelajarkan, di mana pelaksanaan evaluasi dalam penelitian ini bertujuan untuk mengukur pemahaman siswa mengenai materi bangun ruang dan kaitannya dengan bangun datar. Pengembangan instrumen dilakukan dengan cara pengujian validitas, pengujian reliabilitas, perhitungan daya pembeda dan perhitungan taraf kesukaran.

\section{Analisis Data}

Analisis data hasil tes dimaksudkan untuk mengetahui efektivitas STM (Sains Teknologi Masyarakat) dalam meningkatkan pemahaman siswa kelas IV sekolah dasar mengenai konsep energi dan kegunaannya. Teknik analisis data yang digunakan pada penelitian ini yaitu teknik statistik inferensial parameter, di mana teknik ini dilaksanakan dengan menggunakan uji t, taraf signifikansi 0,05.

\section{Prosedur Penelitian}

Penelitian

menggunakan

metode

dengan

experimental design bentuk

nonequivalent groups pretest-posttets design ini dilaksanakan dengan prosedur pelaksanaan penelitian sebagai berikut: Pertama, perencanaan dan persiapan penelitian, dimana pada proses ini dimulai dengan mendefinisikan masalah penelitian, mencari bahan rujukan, dan membuat hipotesis penelitian, menentukan desain penelitian, kemudian memilih sampel dari populasi tertentu sesuai dengan desain penelitian yang telah dipilih, serta membuat Rencana Pelaksanaan Pembelajaran (RPP) STM (Sains Teknologi Masyarakat) dan instrumen-instrumen yang digunakan ketika penelitian. Kedua, pelaksanaan penelitian, di mana pelaksanaan penelitian ini dilakukan dengan penempatan sampel pada kelompok eksperimen dan kelompok kontrol, memberi pretes masingmasing kelompok, didasarkan pada variabel dependent, mengatur kondisi perlakuan terhadap kelompok eksperimen bukan kepada kelompok kontrol, dan melakukan perlakuan atau treatment pelaksanaan STM (Sains Teknologi Masyarakat) terhadap kelompok eksperimen, dan pembelajaran konvensional terhadap kelompok kontrol, serta masingmasing kelompok diberi posttes sesuai dengan variabel dependent. Ketiga, pengumpulan data dan analisis data yang telah diperoleh. Keempat, membuat laporan penelitian.

\section{HASIL PENELITIAN}

Hasil uji-t pemahaman matematis pada saat pretes yaitu bahwa nilai signifikansi (P-value) untuk faktor pembelajaran sebesar $0,919 \geq 0,05$ maka $\mathrm{H}_{0}$ diterima. Dengan kata lain, tidak terdapat perbedaan rerata skor pretes pemahaman matematis siswa antara kelompok kontrol dan kelompok eksperimen berdasarkan faktor pembelajaran. Akan tetapi, hasil uji perbedaan rerata posttes pemahaman matematis siswa yaitu bahwa nilai signifikansi (P-value) untuk faktor pembelajaran sebesar 
$0,000<0,05$ maka $\mathrm{H}_{0}$ ditolak. Dengan kata lain, terdapat perbedaan rerata skor posttes pemahaman matematis siswa antara kelompok kontrol dengan kelompok eksperimen. Adapun hasil perhitungan uji perbedaan rerata dapat dilihat pada tabel 5 berikut ini.

Tabel 5

Tabel Hasil Pengujian Perbedaan Rerata Pemahaman Siswa

\begin{tabular}{|c|c|c|c|c|c|c|c|}
\hline & Pembelajaran & $\begin{array}{c}\text { Perbed } \\
\text { aan }\end{array}$ & $\mathrm{T}_{\text {hitung }}$ & $\mathrm{Df}$ & $\mathrm{t}_{\text {tabel }}$ & Sig. & $\mathrm{H}_{0}$ \\
\hline $\begin{array}{c}\text { Pret } \\
\text { es }\end{array}$ & $\begin{array}{c}\text { Kontrol- } \\
\text { Eksperimen }\end{array}$ & $\mathbf{6 2 < 6 3}$ & $\mathbf{- 0 , 1 0 2}$ & $\mathbf{3 8}$ & $\mathbf{2 , 0 2 4}$ & $\mathbf{0 , 9 1 9}$ & diterima \\
\hline $\begin{array}{c}\text { Post } \\
\text { Kontrol- }\end{array}$ & $\begin{array}{c}\text { Eksperimen } \\
\text { tes }\end{array}$ & $\mathbf{7 6 < 8 9}$ & $\mathbf{- 4 , 1 0 1}$ & $\mathbf{3 8}$ & $\mathbf{2 , 0 2 4}$ & $\mathbf{0 , 0 0 0}$ & ditolak \\
\hline
\end{tabular}

Jika dilihat dari tabel 5 di atas, rata-rata skor pretes kemampuan pemahaman siswa kelompok eksperimen dan kontrol masingmasing adalah adalah 63 dan 62 . Berdasarkan hasil uji perbedaan ratarata diperoleh bahwa rata-rata kedua kelompok tersebut tidak memiliki perbedaan yang signifikan. Dalam hal ini dapat disimpulkan bahwa kemampuan awal pemahaman matematika siswa kelompok eksperimen dan kelompok kontrol adalah sama.

Setelah dilakukan treatment (perlakuan) terhadap kelompok eksperimen dengan menggunakan STM (Sains Teknologi Masyarakat) dan kelompok kontrol dengan menggunakan pembelajaran konvensional sebanyak tujuh treatment pada masing-masing kelas, maka diperoleh rata-rata skor postes kelompok eksperimen adalah 89 dan kelompok kontrol adalah 76. Dengan memperhatikan rata-rata skor posttes antara kelompok eksperimen dan kelompok kontrol dapat disimpulkan bahwa kemampuan pemahaman kelompok eksperimen lebih baik daripada kelompok kontrol secara signifikan.
Rerata skor pretes siswa kelompok eksperimen (63) dan kelompok kontrol (62) relatif sama. $\mathrm{Hal}$ tersebut ditunjukkan oleh perbedaan rerata yang hanya 1 . Namun rerata skor posttes siswa kelompok eksperimen (89) dan kelompok kontrol (76) berbeda sebesar 13. Kenaikan rerata skor posttes dari skor pretes kelompok eksperimen 26, dan kenaikan rerata skor posttes dari skor pretes kelompok kontrol hanya 14.

Hal tersebut memberikan asumsi bahwa kualitas peningkatan pemahaman siswa kelompok eksperimen lebih baik. Untuk lebih jelasnya, berikut diagram yang menunjukkan perbandingan pemahaman kedua kelompok dilihat dari rata-rata hasil pretes-posttes.

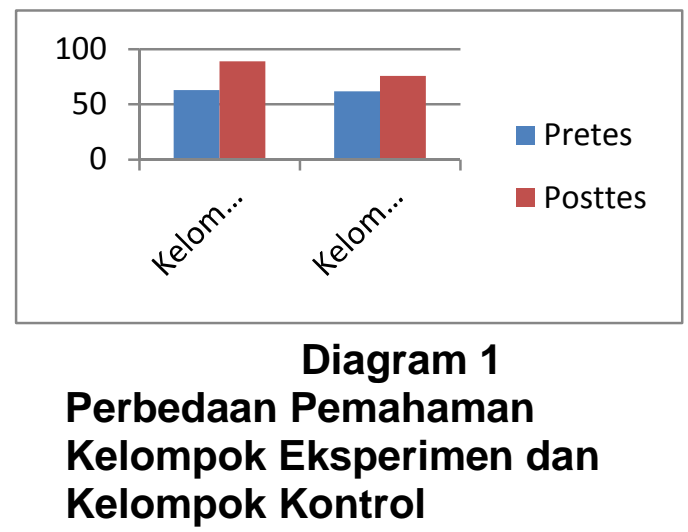

Hasil Uji signifikansi terhadap perbedaan rerata skor postes kelompok eksperimen dengan rerata skor postes kelompok kontrol diperoleh bahwa, dalam tingkat keberartian $\alpha=0,05$ secara meyakinkan terdapat perbedaan yang signifikan antara rerata skor postes kelompok eksperimen dengan rerata skor posttes kelompok kontrol. Peningkatan rerata hasil kemampuan pemahaman siswa kelas ekperimen lebih besar daripada rerata hasil kemampuan pemahaman siswa kelompok kontrol, sehingga dapat 
diketahui bahwa STM (Sains Teknologi Masyarakat) lebih berpengaruh secara signifikan daripada pembelajaran konvensional dalam meningkatkan kemampuan pemahaman siswa sekolah dasar.

\section{KESIMPULAN}

Sejalan dengan rumusan masalah dan pertanyaan penelitian, studi ini memperoleh kesimpulan yang berkenaan dengan hasil studi empirik tentang eksperimen STM (Sains Teknologi Masyarakat) dalam meningkatkan pemahaman siswa kelas IV sekolah dasar. Berdasarkan hasil penelitian yang diperoleh, maka dapat diambil kesimpulan bahwa STM (Sains Teknologi Masyarakat) lebih efektif dalam meningkatkan pemahaman siswa dibandingkan pembelajaran konvensional, hal ini ditandai dengan terdapatnya perbedaan rerata skor posttes pemahaman siswa antara kelompok eksperimen yang menggunakan STM (Sains Teknologi Masyarakat) dengan kelompok kontrol yang menggunakan pembelajaran konvensional. Kemampuan pemahaman siswa yang memperoleh pembelajaran STM (Sains Teknologi Masyarakat) lebih baik daripada siswa yang memperoleh pembelajaran konvensional. Selain itu, siswa pada kelompok eksperimen memberikan respon yang baik dan merasa senang terhadap pembelajaran STM (Sains Teknologi Masyarakat). Sehingga STM (Sains Teknologi Masyarakat) dapat dijadikan alternatif yang efektif dalam meningkatkan kemampuan pemahaman siswa sekolah dasar.

\section{DAFTAR PUSTAKA}

Fraenkel, J. R. dan Wallen, N. E. (2007). How to Design and Evaluate Research in Education. New York: Mcgraw hill.

Munaf. (2001). Pengertian pemahaman. [Online]. Tersedia : http:// yogapw.wordpress.com/2010/1 0/01/klasifikasi-kognitiftaksonomi-bloom/yoga $[10$ Januari 2010]

Poedjiadi, A. (2005). Sains Teknologi Masyarat: Model Pembelajaran Kontekstual Bermuatan Nilai. Bandung:

Remaja Rosdakarya.

Raja, K. P. (2009). Examintion of the science-technology-society with curriculum approach. [Online]. Tersedia:

http://www.cedu.niu.edu/ scied/courses/ciee344/course files_king/sts_reading.htm. [ 6 Oktober 2011]

Wahyono, B. (2008). IImu Pengetahuan Alam di Kelas IV $S D$. Jakarta: Pusat Perbukuan Departemen Pendidikan Nasional.

Widyatiningtyas, R. (2009). Pembentukan Pengetahuan Sains, Teknologi dan Masyarakat dalam Pandangan Pendidikan IPA. EDUCARE: Jurnal Pendidikan dan Budaya. [Online]. Tersedia: http://educare.e-fkipunla.net. [9 Oktober 2011] 
Didaktik : J urnal Pendidikan G uru Sekolah Dasar, ISSN : 2477-5673

Sekolah Tinggi Keguruan dan IImu Pendidikan Subang Volume I Nomor 1, Desember 2015

Yuliariatiningsih, M. S. \& Irianto, D. M. (2008). Pendidikan IPA di Sekolah Dasar. Bandung: UPI Kampus Cibiru.

Yunansah. H. (2009). Model pembelajaran berbasis
Fenomene untuk meningkatkan pemahaman Konsep Fluida Statis dan keterampilan proses Sains Siswa SMA. Tesis SPS UPI. Bandung: Tidak diterbitkan 